ORIGINAL ARTICLE

\title{
The Effectiveness of the Implementation of Kangaroo Treatment Method in Increasing the Weight Gain of Newborns With LBW
}

\section{Cicih Nurcholishah*, Syatirah Djalaluddin, Fhirastika Annisha}

Faculty of Medicine and Health Sciences, Universitas Islam Negeri Malang, Indonesia

\section{ARTICLE INFO}

Article history:

Received:

January 21, 2022

Received in revised form :

February 20, 2022

Accepted:

February 23, 2022

\section{Keywords:}

Effectiveness,

Kangaroo Method Care,

Birth Weight,

$L B W$

*) Corresponding author:

cicinurkhalisa@gmail.com

\begin{abstract}
Background: Low body weight (LBW) cases have continuously occurred. However, some newborns with LBW could not afford good and hightechnological health services due to several barriers such as cost, geography, transportation, and communication barriers. Incubator replacement through kangaroo treatment method is considered to be an effective and economical alternative in which the weight gain in newborns with LBW could be enhanced. Kangaroo care method can be used in treating newborns with low birth weight. The purpose of this study was to identify the effectiveness of the implementation of the kangaroo care method in increasing the weight gain of newborn with LBW at the General Hospital of Majene.
\end{abstract}

Methods: The research design used in this study was a pre-experiment with One Group Pretest Posttest Design. The sampling method used in this research was total sampling where 38 samples were selected. This research was conducted at the Regional Hospital of Majene in the Perinatology room.

Results: The results of this research indicated that there were significant differences in newborns before and after the implementation of the Kangaroo care method. It was evident that the newborns weight significantly increase with the Kangaroo care method. Therefore, further research should be carried out to investigate the factors which influence the increase of newborns weight.

Conclusion: In this study we found that there were significant differences in LBW babies before and after being treated with the kangaroo method (PMK).

Medical and Health Science Journal 


\section{Introduction}

Low birth weight (LBW) is a birth weight of fewer than 2500 grams regardless of gestational age. Birth weight is the weight of an infant weighed within 1 hour after birth. LBW can occur in preterm infants $(<37$ weeks) or in full-term infants (intrauterine growth restriction / IUGR). ${ }^{1} \mathrm{LBW}$ has a 20 times greater risk of dying during infancy when compared to babies with normal birth weight. The infant mortality rate increases with the increase of LBW incidence in a country. ${ }^{2}$

Before finding FMD, incubators were one of the ways to deal with babies LBW or premature, but the use of incubators was considered to inhibit early mother-baby contact and breastfeeding. Given the limited incubator facilities in health services, PMK can be used in treating LBW. This method was first performed in 1979 in Colombia by Martinez, who treated babies weighing less than 1500 grams and the results were satisfactory. ${ }^{3}$ FMD is useful in significantly reducing the number of neonates or newborns who died, avoiding low birth weight babies from being cold (hypothermia), stabilizing babies, reducing the occurrence of infections, increasing infant growth and development, increasing breastfeeding and bonding between mother and baby. ${ }^{4}$

In an attempt to introduce FMD as an appropriate technology to reduce neonatal mortality, this research is one tangible step. ${ }^{5}$ The limited incubator in the room causes two babies in one incubator, that's why the baby has a risk of infection. Based on these reasons, many patients ask to go home prematurely due to cost reasons. So PMK is the right choice to overcome LBW. This research was also conducted the first time in Majene Regency.

\section{Methods}

The Research design used preexperimental, one group pre-test and post-test Design was conducted on a set of objects that did not require a comparison group ${ }^{6}$, the sample of this study was observed before being given treatment, after conduct treatment the sample was reobserved. ${ }^{7}$ The research was conducted in the perinatology room of the Majene Regional Hospital, West Sulawesi Province. The study was conducted for 1 month, starting from December 2020 to January 2021.

The population of this study was all LBW babies who were treated in the perinatology room of the Majene Hospital. The sample in this study were all LBW babies who were treated with kangaroo method care in the perinatology room of the Majene Hospital. Sampling used a total sampling technique by taking samples of babies undergoing kangaroo treatment in the 2020 period. Data collection from this study used secondary data obtained from the research location agency according to the data listed in the research instrument in the form of observation sheets before and after treatment. kangaroo method. Data processing was analyzed using the Statistical for Social Science (SPSS) application using univariate analysis techniques and bivariate analysis. This bivariate analysis was used to connect the independent and dependent variables using the Paired t-test statistical test with a significance level of $\alpha=0.05$. 


\section{Results}

1. Univariat Analysis

Table 1. Characteristic Distribution of Babies

\begin{tabular}{|c|c|c|}
\hline Characteristics & Frequency & Percentage $(\%)$ \\
\hline \multicolumn{3}{|l|}{ Gender } \\
\hline Female & 17 & 44,73 \\
\hline Male & 21 & 55,26 \\
\hline \multicolumn{3}{|l|}{ Gestational Age } \\
\hline Preterm infants & 27 & 71,05 \\
\hline Full-term infants & 11 & 28,94 \\
\hline \multicolumn{3}{|l|}{ Baby Birth Weight } \\
\hline$<2000$ gram & 24 & 63,15 \\
\hline$>2000$ gram & 14 & 36,84 \\
\hline \multicolumn{3}{|l|}{ Infant Weight at Evaluation of LBW } \\
\hline BBLSR & 5 & 13,15 \\
\hline BBLR & 33 & 86,84 \\
\hline \multicolumn{3}{|l|}{ Length of Treatment } \\
\hline$<7$ Hari & 6 & 15,78 \\
\hline 7-14 Hari & 13 & 34,21 \\
\hline$>14$ Hari & 19 & 50 \\
\hline \multicolumn{3}{|l|}{ Complementary Diseases in LBW } \\
\hline \multicolumn{3}{|l|}{ Patients } \\
\hline 1. $\mathrm{RDN}$ & 16 & 42,10 \\
\hline 2. Hiperbilirubin & 17 & 44,73 \\
\hline 3. Feeding Probl & 15 & 39,47 \\
\hline 4. ems & 9 & 23,68 \\
\hline 5. Hypoglycemia & 15 & 39,47 \\
\hline 6. Hypothermia & 8 & 21,05 \\
\hline 7. Granuloma & 7 & 18,42 \\
\hline 8. Pyoderma & 3 & 7,89 \\
\hline 9. $\mathrm{HDN}$ & 3 & 7,89 \\
\hline 10. Asfiksia & 6 & 15,78 \\
\hline 11. Another & & \\
\hline
\end{tabular}

Paired t-test

Data sekunder, 2020 
Table 4.1 shows the characteristics of babies who experience LBW, data obtained using secondary data from medical records recording at Majene Hospital, the results are more male as many as 21 people $(55.25 \%)$, with a full-term baby (BCB). ) as many as 27 people (71.05\%). While the birth weight of babies <2000 grams was 24 people
$(63.15 \%)$, then there were 33 babies $(86.84 \%)$ who were treated with PMK. In addition, the length of treatment> 14 days was 19 people $(50 \%)$, this could be influenced by comorbidities in LBW, namely Hyperbilirubin 17 cases (44.73\%), then RDN 16 cases (42.10\%), then Feeding. Problems and Hypothermia as many as 15 cases (39.47\%).

Table 2. Characteristic Distribution of Mother's Babies

\begin{tabular}{ccc}
\hline \multicolumn{1}{c}{ Characteristic } & Frequency & Percentage \% \\
\hline Mother's age & 10 & $26,31 \%$ \\
$<21$ year & 20 & $52,63 \%$ \\
$21-35$ year & 8 & $21,5 \%$ \\
$>35$ year & & \\
Mother's work & 31 & $81,57 \%$ \\
Doesn't Work & 7 & $18,42 \%$ \\
Work & & \\
Mother's Education & 15 & $39,47 \%$ \\
Elementary- Junior High School & 16 & $42,10 \%$ \\
Senior High School & 7 & $18,42 \%$ \\
Graduate & & \\
\hline
\end{tabular}

Table 4.2 data obtained utilizing secondary data from recording medical records at Majene Hospital, shows that the characteristics of the age of mothers who gave birth to $\mathrm{LBW}$ at Majene Hospital in the January-December 2020 period were the age group of fertile women, namely 21-35 years, as many as 20 people (52.63\%). Meanwhile, the highest level of education for mothers was SMA as many as 16 people $(42.10 \%)$ and mothers who did not work much more, namely as many as 31 people $(81.57 \%)$ when compared to mothers who worked.

Table 3. Weight Changed distribution Before and after PMK in RSUD Majene, Period January-December $2020(n=38)$

\begin{tabular}{l|c|c|l|l}
\hline \multirow{2}{*}{ Variable } & \multirow{2}{*}{ Mean } & \multirow{2}{*}{ Std. } & \multicolumn{2}{|c}{ Mean } \\
\cline { 4 - 5 } & & & Lower & Upper \\
\hline Before PMK & 1973,15 & 364,01 & $22(57,89 \%)$ & $16(42,16 \%)$ \\
After PMK & 2018,07 & 374,86 & $22(57,89 \%)$ & $16(42,16 \%)$ \\
\hline
\end{tabular}

Table 4.3 data obtained using secondary data from recording medical records at the Majene Regional Hospital shows that the results of weight interval estimation can be concluded that $95 \%$ is believed to be the average body weight before kangaroo treatment (PMK) is 1853.51 - 2092.80 grams and 
The average body weight after kangaroo treatment (PMK) was 1894.86 - 2142.29 grams. A distribution of 22 people (57.89) was below the average value before PMK and after PMK. The table shows that the average body weight before PMK was 1973.1558 grams with a standard deviation of 364.01494 grams. The average body weight after PMK was 2018.0761 grams, with a standard deviation of 374.86840 grams. This is descriptive there is a difference in the average before and after PMK.

\section{Bivariate Analysis}

Table 4. Mean Distribution of Baby's Weight Gain before and after PMK in RSUD Majene, Period JanuaryDecember 2020

\begin{tabular}{lccc}
\hline & \multicolumn{2}{c}{ Paired Differences } & P-value \\
\cline { 2 - 3 } & Mean & std. Deviation & \\
\hline Before & 44.92 & 19.46 & 0.000 \\
PMK & & & \\
\cline { 1 - 1 } After & & & \\
PMK & & & \\
\hline
\end{tabular}

Paired t-test

Data sekunder, 2020

The table paired samples test (T-test/ hypothesis test) states that the difference in mean difference before and after 44.92 standard deviations 19.46 . Meanwhile, P-value $0.000<0.005$ or $\mathrm{Ho}$ is rejected. Thus, it is concluded that there are significant differences before PMK and after PMK.

\section{Discussion}

Referring to the results of the evaluation conducted in this study, it was found that the majority of mothers were aged $21-35$ years $(52.63 \%)$ or of childbearing age, who had more energy than those aged> 35 years. So that mothers can take better care of their babies. In addition, in the evaluation results, it was found that the majority of mothers had the characteristics of not working $(81.57 \%)$, which meant that they had sufficient time to carry out PMK while in the hospital and even at home.
But in fact, based on research conducted by Samuel Maju Simanjuntak \& Dina Hartini (2019) states that in their research ${ }^{8}$, the results of the evaluation of the majority of mothers $(96.7 \%)$ have the characteristics of not working, which means they have sufficient time to carry out PMK at home, but in reality, only $10 \%$ of mothers implement PMK, because it is recorded that they receive very little support from their families, as well as a lack of education about PMK for mothers who have LBW so that the implementation of independent PMK is still low.

This study aims to determine the effectiveness of the kangaroo treatment method for changes in body weight. The data obtained is the measurement of body weight which was carried out while being treated in the perinatology room of the Majene Hospital.

Based on data obtained from the medical records section of the Majene Hospital in 2020, there were 
38 cases of babies with LBW who were given PMK treatment during their recovery period. In the evaluation results, it was found that there were more male babies $(55.26 \%)$ than women $(44.73 \%)$, with the majority of term babies $(71.05 \%)$ and the majority were born with birth weights $<2000$ grams. (63.15\%). The evaluation results also found that the majority of the length of stay more than 4 days $(50 \%)$. This level of length of care is supported by the presence of comorbidities in infants with LBW, the majority of infants with LBW also suffer from hyperbilirubin (44.73\%), then RDN (42.10\%) is also a common comorbid disease based on the results of the evaluation in this study.

Based on the results of the study, the researchers argued that where babies with low birth weight (LBW) were given kangaroo treatment, it was closely related to the significant increase in baby weight. The kangaroo method (PMK) treatment process in this study was carried out for 7 days with a minimum PMK time of 1-2 hours per day. Infants with LBW who received PMK experienced a significant increase.

The results showed that of the 38 respondents who received PMK for one week, there was a significant influence between body weight before and after PMK p-value 0,000, with the average difference between before and after PMK was 44.92 grams per week. This increase is not much different from the results presented by Siti Dewi Rahmayanti (2010) that the increase in body weight in infants with LBW shows that the average body weight before treatment without FMD is 2050.00 grams with a standard deviation of 290.48 grams. ${ }^{9}$ The average body weight after treatment without FMD was 2156.25 grams, with a standard deviation of 330.593 grams.
This study is also in line with previous research conducted by Putri \& Gusmila in 2014 which said that there was a difference in the average weight of babies before and after treatment with the kangaroo method in the perinatology room of Dr. Achmad Mochtar Bukittinggi, where the results showed that there was a significant difference between the average body weight of babies before the kangaroo method treatment and after the kangaroo method treatment with an average baby weight of 28.30 grams with a standard deviation of 3.093. ${ }^{10}$

This is also put forward by the 2013 Maryuani theory ${ }^{11}$, writing that the benefits of PMK for mothers are to increase prematurity baby weight or low birth weight, by stabilizing heart rate, breathing patterns and oxygen saturation, providing warmth to babies, increasing sleep duration, reducing infant crying and calorie requirements, accelerate weight gain and brain development, increase success and prolong the duration of breastfeeding.

This is following research conducted by Mardiani Freari, Agonwardi 2017, in her research proving the effectiveness of the kangaroo method to increase the weight of babies with LBW. Based on the research concept framework, the application of the kangaroo method can increase the baby's weight optimally. ${ }^{12}$ This is because a baby born with a low birth weight (LBW) baby will generally be put in an incubator so that his body temperature remains normal and given oxygen assistance for interpretation and low birth weight (LBW) babies can also experience mental and physical disorders at growing age. ${ }^{13}$ flower further, so that the maintenance requires high maintenance costs, in addition to the incubator the baby's body temperature can be maintained warmly by the kangaroo method. In the past, this method was 
considered only for the poor because the rich were put in an incubator, but based on experience, the result is the kangaroo method is even more effective.

The kangaroo method itself can increase the ability of babies to suck, with good sucking ability in babies with low birth weight (LBW), ${ }^{14}$ it will stimulate the formation of the hormone oxytocin and increase the hormone prolactin which will help milk production, so that the mother can produce breast milk that is sufficient for the needs of the baby, the baby freely gets breast milk in a timely manner and whenever the baby needs it. ${ }^{15}$

\section{Conclusion}

BBLR is an accident from Allah SWT to His creations. Islam emphasizes the importance of effort and prayers. In the Qur'an, it says that humans will not get anything other than what they work for, and the results of their efforts will be shown (to them), then they will be rewarded with an appropriate result according to Surah Ar Rad verse 11 . One of the efforts that can be done is by Kangaroo Method Care (PMK).

From this study, it was found that the characteristics of the sample of babies were more male, with a full-term gestation age who passed treatment for more than 14 days because they were generally accompanied by comorbidities other than LBW. In this study, it was found that there were more mothers with low birth weight patients of productive age with secondary education and who work as housewives. From the research, it was found that there were significant differences in LBW babies before and after being treated with the kangaroo method (PMK).

\section{Acknowlegment}

The financing is obtained independently

\section{Conflict of Interest}

The author stated there is no conflict of interest

\section{References}

1. Pudhadi, Antonius. Pedoman Pelayanan Medis IDAI Jilid I (2010). Jakarta Ikatan Dokter Anak Indonesia (IDAI), 2010

2. Sujianti, S. Literature review bayi berat lahir rendah. J. Kesehat. Ibu dan Anak 11, 75-81 (2017).

3. Putri, W. Faktor Ibu terhadap Kejadian Bayi Berat Lahir Rendah. Higea J. Public Heal. Res. Dev. 3, 55-62 (2019).

4. Hastuti, P. Pendidikan Kesehatan Meningkatkan Praktik Perawatan Metode Kanguru ( Pmk) Pada Ibu Nifas Dengan Bayi Berat Lahir Rendah. J. Ris. Kesehat. 7, 32 (2018).

5. Endyarni, B. Perawatan Metode Kanguru (PMK) Meningkatkan Pemberian ASI. https://www.idai.or.id/artikel/klinik/asi/p erawatan-metode-kanguru-pmkmeningkatkan-pemberian-asi (2013).

6. Notoadmodjo, S. Metodologi Penelitian Kesehatan. (PT. Rineka Cipta, 2012).

7. Hidayat, A. A. Metode Penelitian Keperawatan dan Teknik analisis Data/A. Aziz Alimul Hidayat. (Jakarta Salemba Medika, 2009).

8. Simanjuntak, S. \& Hartini, D. Kenaikan Berat Badan (BBLR) melalui Pelaksanaan Perawatan Metode Kanguru (PMK) di Rumah. J. Smart Keperawatan 6, 73 (2019). 
9. Rahmayanti, S. D. Pengaruh perawatan metode kanguru terhadap pertumbuhan bayi, pengetahuan dan sikap ibu dalam merawat BBLR di RSUD Cibabat Cimahi [Influence of kangaroo method on babys growth, mothers knowledge and attitude in low birth weight care at Cibabat Hospital, Cimahi]. Yani Cimahi (2010).

10. Yelmi, S. Pengaruh Perawatan Metode Kanguru terhadap Perubahan Berat Badan Bayi Lahir Rendah. J. Ipteks Terap. 9, 11-19 (2015).

11. Anik, M. Asuhan Bayi dengan Berat Badan Lahir Rendah (BBLR). (2013).

12. Bebasari, mardiani, agonwardi, agonwardi \& nandiati, nandiati. Pengaruh Perawatan Metode Kanguru Terhadap Kenaikan Berat Badan Pada Bayi Berat Badan Lahir Rendah Di Ruang Perinatologi Rsud Dr. Rasidin
Padang Tahun 2017. Jik- J. Ilmu Kesehat. 1, 32-38 (2017).

13. Décima, P. et al. Does the incubator control mode influence outcomes of lowbirth-weight neonates during the first days of life and at hospital discharge? Health (Irvine. Calif). 05, 6-13 (2013).

14. Heidarzadeh, M., Hosseini, M. B., Ershadmanesh, M., GholamitabarTabari, M. \& Khazaee, S. The Effect of Kangaroo Mother Care (KMC) on Breast Feeding at the Time of NICU Discharge. Iran. Red Crescent Med. J. 15, 302-306 (2013).

15. Galoustian, G. Mother/Infant Skin-ToSkin Touch Boosts Baby's Brain Development. https://www.fau.edu/newsdesk/articles/k angaroo-care-study.php (2020). 